\title{
Spiritual Needs of Patients with a Colostomy in a Public Hospital
}

\author{
Rahmatia Mozaike Ramdani, Chandra Isabella Hostanida Purba, Atlastieka Praptiwi \\ Faculty of Nursing, Universitas Padjadjaran \\ Email: rahmatiamozaike@yahoo.com
}

\begin{abstract}
An intestinal stoma is an opening of the intestinal tract into the abdominal wall for patients with feces production problems. The process might change patients' physical, psychological, social, and spiritual. Patients have limitations in daily activities, changes in elimination, depression, feeling hopeless, ashamed with the colostomy bag, and may also affect to their religious and spiritual. For example their religious rituals and belief in God. The aim of this study was to identify the spiritual need of patients with a colostomy in a public hospital in Bandung. This was a descriptive quantitative study, The population was patients with a colostomy who hospitalized in a public hospital in Bandung. The samples were chosen using the accidental sampling $(\mathrm{n}=42)$ technique. The study instrument was Spiritual Needs Questionaire (SpNQ), that consists of 19 questions with 4 dimensions (religious needs, inner peace, existential, and actively giving). Data were analyzed using statistics descriptive and presented in a table of distribution frequency. The study found that patients with a colostomy had the spiritual need for all dimension including the religious dimension $(88,1 \%)$, inner peace $(57,1 \%)$, existential $(54,8 \%)$, and actively giving $(52,4 \%)$. Patients with a permanent colostomy had higher scores on the spiritual needs than those temporary colostomy patients. It can be concluded that the religious dimension is the highest relevance of the spiritual needs. According to this study results, it is expected that nurses can improve the spiritual services in nursing care including assessing patients' spiritual needs and facilitating patients to fulfill their spiritual needs. The facilitation includes providing an opportunity for praying together, spiritual books, helping patients for ritual worship, establishing therapeutic communication, giving patients their own time, and creating a quiet place.
\end{abstract}

Keywords: Colostomy, hospitalized patients, spiritual needs. 
Rahmatia Mozaike : Spiritual Needs of Patients with A Colostomy

\section{Introduction}

A colostomy is a connection hole (stoma) of the colon to the skin of the abdominal wall which aims to remove feces and gas (Smeltzer $\&$ Bare, 2002). There are two types of stoma, a permanent stoma is for patients who can not defecation via the anus, and a temporary stoma for patients who need a temporary resting of distal intestine to empty or sterile the colon (Burch, 2013; Shenoy \& Nileshwar, 2014). According to the International Agency for Research on Cancer (IARC) in 2012, colorectal cancer was the third rank of cancer worldwide after lung cancer and breast cancer with the number of incidence $17.2 \%$ and $8.4 \%$ of the mortality rate.

According to the World HealthOrganization (WHO) data in 2012, the most common cancer was colorectal cancer. Colorectal cancer was the third rank of male cancer after lung cancer and prostate cancer, which was 746,000 cases, or $10.0 \%$ of total cancer in the world, and the second rank of female cancer after breast cancer, the cases was 614,000 , or $9.2 \%$ of total worldwide (Globocan, 2012). Indonesian Ostomy Association (InOA) reported that in Indonesia, the number of stoma cases increased, and the most common cause was malignancy (Indonesian Ostomy Association, 2010). In 2012, there were 5000 ostomates in Indonesia and it increases every year (Asia South Pacific Ostomy Association, 2013). Other data from the Medical Records General Hospital in Bandung showed that the number of patients who performed colostomy actions was 99 patients in 2016, however, this data did not specify patients' indication for a colostomy.

Although stoma has an important function, it would also lead to physical, psychological, social, and spiritual changes (Ranki, Ibrahim, \& Nuraeni, 2014). When an illness is life-threatening for an individual, then the most important coping strategies are religion, and spirituality (Johnson, Piderman, Sloan, Huschka, Atherton, \& Hanson, 2007). Patients often report about the unmet need for spiritual and existential, on the other hand, the spiritual support is related to improving the quality of life (Bussing \& Koenig, 2010). A descriptive study conducted by Helen (2014) to patients $(n=37)$ with a permanent intestinal stoma in Dharmais Hospital found that $90 \%$ of them had a good quality of life. However, the distribution of the domain of the quality of life showed that $83.8 \%$ of respondents had poor spiritual needs, and $81.1 \%$ of Muslim respondents reported that their 5 times prayers disrupted because of flatus or stool out during the prayer. Respondents also said that the stoma did not bring positive changes in their lifestyle.

Baldwin's (2008) study about the impact of stoma on the quality of spiritual life of American veterans $(n=239)$ found that the quality of life of the upper quartile group $(\mathrm{n}=$ 59) had the lowest of a spiritual domain with a mean of $8.32(\mathrm{SD}=1.43)$, and the bottom quartile group $(n=61)$ had the highest of spiritual domain with a mean 4.30 (SD = 2.41), although the majority of patient had a high quality of life, it was not a guarantee that they also had a high spiritual quality.

Yulianti's study (2016) of the spiritual welfare of patients with an intestinal stoma in Hospital Dr. Hasan Sadikin $(\mathrm{n}=32)$ found that $78.1 \%$ of respondents had spiritual welfare in the medium category. For the welfare of existential had average $42.94(\mathrm{SD}=6,956)$. There were two lowest aspects which are the satisfaction and enjoy life. The religion welfare aspect had the average 47,94 (SD = 5,303), in this aspect, the respondents lowest average was the satisfaction of praying to God.

Preliminary data from the public hospital in Bandung found that 3 patients expressed surprise after the stoma surgery and felt sad, patients felt uncomfortable after the colostomy, especially when doing activities and praying because they felt dirty, fear because tough only himself who experienced colostomy, and said from the beginning that he/she was not able to accept these conditions. In patients with a colostomy, they felt unperfect, stress, uncomfortable with the stomach pouch, and embarrassed when meeting others. These conditions were the causes of patients' spiritual distress. Maruta's (2003) study revealed that spiritual distress can be prevented by knowing the spiritual needs as well as support from various sources to meet the spiritual needs. A patient in prospering spiritually if they met their spiritual needs, then the spiritual welfare had 
Rahmatia Mozaike : Spiritual Needs of Patients with A Colostomy

an important role in improving the quality of life of patients. Based on those descriptions, this study is aimed to assess the spiritual needs of patients with a colostomy in a public hospital in Bandung.

\section{Research Method}

This was a descriptive quantitative study. The variable of this study was the spiritual needs of patients with a colostomy. The population of this study was patients with a colostomy who hospitalized in a public hospital in Bandung. The samples were chosen using the accidental sampling technique $(n=42)$. The instrument of this study was the Spiritual Needs Questionnaire (SpNQ) that developed by Büssing, Balzat, dan Heusser (2010). The instrument consists of 19 questions of four dimensions which are religious needs, inner peace, existential, and actively giving. The $\mathrm{SpNq}$ instrument originally was written in English, in this study the researcher used the SpNQ instrument that translated to Bahasa Indonesia by Nur Laili Fithriana; a staff of PSIK FK Diponegoro Univerity. The reliability, this SpNQ 2.1 questionnaire had internal consistency 0.74-0.92. Religion $($ alpha $=0,92)$, inner peace $($ alpha $=0,82)$, existential (alpha $=0,82)$, and actively giving $($ alpha $=0,74)$.

This study was conducted in a public hospital in Bandung from 25 July to 14 August 2017. The data were analyzed using descriptive statistics which produces the distribution and frequency. In terms of scoring, the first was the spiritual needs of the respondents (yes/no). Then assess the patients' spiritual needs using scale $0-3$. Respondents rated 0 if they chose "no", given the value of 1 if they chose the statement "a little", respondents rated 2 when chose "very" and they rated 3 when they chose "extremely". To score distribution is as follows: score $0=$ No Need, score $1-1,9=$ Somewhat Need, score $=$ 2-2,9 It took, score $3=$ Extremely Need.

\section{Research Results}

Table 1 present that more than half of respondents aged between 36-60 years,

Table 1 The Frequency Distribution of Characteristic Patients With a Colostomy in a Public Hospital in Bandung $(\mathrm{n}=42)$

\begin{tabular}{lcc}
\hline \multicolumn{1}{c}{ Characteristic } & Frequency (f) & Persentase (\%) \\
\hline \multicolumn{1}{c}{ Agears) } & & \\
\hline $20-35$ (Young Adult) & 6 & 14.3 \\
$36-60$ (Middle Aged) & 25 & 59.5 \\
61-70 (Older Adult) & 11 & 26.2 \\
Gender & & \\
Male & 27 & 64.3 \\
Female & 15 & 35.7 \\
Religion & & \\
Islam & 39 & 92.9 \\
Cristiani & 3 & 7.1 \\
Tribes & & \\
Sundanese & 34 & 81.0 \\
Javanese & 7 & 16.7 \\
Batak & 1 & 2.4 \\
Pendidikan Terakhir & & \\
Uneducated & 2 & 4.8 \\
Elementary & 24 & 57.1 \\
Junior High School & 5 & 11.9 \\
\hline
\end{tabular}


Rahmatia Mozaike : Spiritual Needs of Patients with A Colostomy

\begin{tabular}{lcc}
\hline Senior High School & 7 & 16.7 \\
College & 1 & 2.4 \\
University & 3 & 7.1 \\
Occupation & & \\
Employee & 25 & 59.5 \\
Unemployee & 17 & 40.5 \\
Earnings & & \\
$<$ UMR & 32 & 76.2 \\
> UMR & 10 & 23.8 \\
Marital Status & & \\
Married & 42 & 100.0 \\
Unmarried & 0 & 0 \\
Diagnosis & & \\
Ca Recti & 22 & 52.4 \\
Ca Colon & 20 & 47.6 \\
Duration of Colostomy Treatment & & \\
$1-30$ hari & 11 & 26.2 \\
31-60 hari & 4 & 9.5 \\
61-90 hari & 2 & 4.8 \\
$>90$ hari & 25 & 59.5 \\
Types of Colostomy & & 54.8 \\
Permanent & 23 & 45.2 \\
Temporary & 19 & \\
\hline
\end{tabular}

Table 2 The Frequency Distribution of Patients' Spiritual Needs with a Colostomy in a Public Hospital Bandung $(n=42)$

\begin{tabular}{|c|c|c|c|c|c|c|c|c|}
\hline \multirow[t]{3}{*}{ Dimension } & \multicolumn{8}{|c|}{ Needs Criteria } \\
\hline & \multicolumn{2}{|c|}{ A Little } & \multicolumn{2}{|c|}{ Very } & \multicolumn{2}{|c|}{ Extremely } & \multicolumn{2}{|c|}{ No } \\
\hline & f & $\%$ & f & $\%$ & f & $\%$ & f & $\%$ \\
\hline $\begin{array}{l}\text { Religious } \\
\text { needs }\end{array}$ & 5 & 11.9 & 32 & 88.1 & 0 & 0.0 & 0 & 0.0 \\
\hline Inner peace & 15 & 35.7 & 24 & 57.1 & 3 & 7.1 & 0 & 0.0 \\
\hline Existensial & 19 & 45.2 & 23 & 54.8 & 8 & 0.0 & 0 & 0.0 \\
\hline $\begin{array}{l}\text { Actively } \\
\text { giving }\end{array}$ & 19 & 45.2 & 22 & 52.4 & 2 & 2.4 & 0 & 0.0 \\
\hline
\end{tabular}

Tabel 3 The frequency distribution of Spiritual Needs of Patients with Colostomy $(n=42)$

\begin{tabular}{|c|c|c|c|c|c|c|c|c|c|}
\hline \multirow[t]{3}{*}{ Dimension } & \multirow{3}{*}{$\begin{array}{c}\text { Types of } \\
\text { colostomy }\end{array}$} & \multicolumn{8}{|c|}{ Needs Criteria } \\
\hline & & \multicolumn{2}{|c|}{ A little } & \multicolumn{2}{|c|}{ Very } & \multicolumn{2}{|c|}{ Extremely } & \multicolumn{2}{|c|}{ No } \\
\hline & & f & $\%$ & f & $\%$ & f & $\%$ & $\mathbf{f}$ & $\%$ \\
\hline \multirow{2}{*}{$\begin{array}{l}\text { Religious } \\
\text { needs }\end{array}$} & Permanent & 3 & 7.1 & 20 & 47.6 & 0 & 0.0 & 0 & 0.0 \\
\hline & Temporary & 2 & 4.8 & 17 & 40.5 & 0 & 0.0 & 0 & 0.0 \\
\hline \multirow[t]{2}{*}{ Inner peace } & Permanent & 9 & 21.4 & 14 & 33.3 & 0 & 0.0 & 0 & 0.0 \\
\hline & Temporary & 6 & 14.3 & 10 & 23.8 & 3 & 7.1 & 0 & 0.0 \\
\hline
\end{tabular}


Rahmatia Mozaike : Spiritual Needs of Patients with A Colostomy

\begin{tabular}{llcccccccc}
\hline Existensial & Permanent & 10 & 23.8 & 13 & 31.0 & 0 & 0.0 & 0 & 0.0 \\
& Temporary & 9 & 21.4 & 10 & 23.8 & 0 & 0.0 & 0 & 0.0 \\
Actively & Permanent & 11 & 26.2 & 11 & 26.2 & 1 & 2.4 & 0 & 0.0 \\
giving & Temporary & 8 & 19.0 & 11 & 26.2 & 0 & 0.0 & 0.0 & 0.0 \\
\hline
\end{tabular}

Table 4 Spiritual Needs

\begin{tabular}{|c|c|c|c|c|c|c|c|c|}
\hline \multirow[t]{2}{*}{ Dimension } & \multicolumn{2}{|c|}{ No Need } & \multicolumn{2}{|c|}{ A Little } & \multicolumn{2}{|c|}{ Very } & \multicolumn{2}{|c|}{ Extremely } \\
\hline & f & $\%$ & f & $\%$ & f & $\%$ & f & $\%$ \\
\hline \multicolumn{9}{|c|}{ Religious needs } \\
\hline $\begin{array}{l}\text { Praying together with } \\
\text { family or others }\end{array}$ & 0 & 0.0 & 0 & 0.0 & 14 & 33.3 & 28 & 66.7 \\
\hline $\begin{array}{l}\text { Asking to be prayed by } \\
\text { family or others }\end{array}$ & 0 & 0.0 & 0 & 0.0 & 12 & 28.6 & 30 & 71.4 \\
\hline Self Praying & 0 & 0.0 & 0 & 0.0 & 15 & 35.7 & 27 & 64.3 \\
\hline $\begin{array}{l}\text { Participating in religious } \\
\text { events }\end{array}$ & 0 & 0.0 & 17 & 40.5 & 20 & 47.6 & 5 & 11.9 \\
\hline $\begin{array}{l}\text { Reading a spiritual book or } \\
\text { religious book }\end{array}$ & 0 & 0.0 & 26 & 61.9 & 12 & 28.6 & 4 & 9.5 \\
\hline $\begin{array}{l}\text { Making close relationship } \\
\text { with God }\end{array}$ & 0 & 0.0 & 0 & 0.0 & 23 & 54.8 & 19 & 45.2 \\
\hline \multicolumn{9}{|c|}{ Inner peace } \\
\hline $\begin{array}{l}\text { Talking to others about } \\
\text { fear and worry }\end{array}$ & 2 & 4.8 & 8 & 19.0 & 17 & 40.5 & 15 & 35.7 \\
\hline $\begin{array}{l}\text { Enjoying the beauty of } \\
\text { nature }\end{array}$ & 0 & 0.0 & 10 & 23.8 & 23 & 54.8 & 9 & 21.4 \\
\hline $\begin{array}{l}\text { Staying in a quiet and } \\
\text { peaceful place }\end{array}$ & 0 & 0.0 & 5 & 11.9 & 27 & 64.3 & 10 & 23.8 \\
\hline Finding inner peace & 0 & 0.0 & 4 & 9.5 & 20 & 47.6 & 18 & 42.9 \\
\hline Becoming a caring person & 0 & 0.0 & 9 & 21.4 & 25 & 59.5 & 8 & 19.0 \\
\hline \multicolumn{9}{|c|}{ Existential } \\
\hline $\begin{array}{l}\text { Reflecting on the previous } \\
\text { life }\end{array}$ & 1 & 2.4 & 12 & 28.6 & 20 & 47.6 & 9 & 21.4 \\
\hline $\begin{array}{l}\text { Finding the meaning of } \\
\text { pain or suffering }\end{array}$ & 1 & 2.4 & 8 & 19.0 & 24 & 57.1 & 9 & 21.4 \\
\hline $\begin{array}{l}\text { Talking to other people } \\
\text { about the meaning of life }\end{array}$ & 0 & 0.0 & 5 & 11.9 & 28 & 66.7 & 9 & 21.4 \\
\hline $\begin{array}{l}\text { Talking to other people } \\
\text { about the possibility of life } \\
\text { after death }\end{array}$ & 1 & 2.4 & 22 & 52.4 & 18 & 42.9 & 1 & 2.4 \\
\hline $\begin{array}{l}\text { Forgiving someone from } \\
\text { the past }\end{array}$ & 2 & 4.8 & 1 & 2.4 & 19 & 45.2 & 20 & 47.6 \\
\hline \multicolumn{9}{|c|}{ Actively giving } \\
\hline Being the solace of others & 0 & 0.0 & 16 & 38.1 & 22 & 52.4 & 4 & 9.5 \\
\hline $\begin{array}{l}\text { Sharing life experiences to } \\
\text { others }\end{array}$ & 0 & 0.0 & 6 & 14.3 & 33 & 78.6 & 3 & 7.1 \\
\hline $\begin{array}{l}\text { Essuring that your life is } \\
\text { meaningful }\end{array}$ & 0 & 0.0 & 6 & 14.3 & 33 & 78.6 & 3 & 7.1 \\
\hline
\end{tabular}


Rahmatia Mozaike : Spiritual Needs of Patients with A Colostomy

and most respondents were males $(64.3 \%)$. All respondents are married, almost all respondents are Moslems, and $85 \%$ of respondents are ethnic Sundanese. The education level of respondents is more than half of them had an elementary education, and $60 \%$ of respondents are working with $(76.2 \%)$ salary under national standard. More than half of respondents $(52.4 \%)$ were diagnosed $\mathrm{Ca}$ Recti with permanent colostomy type $(54.8 \%)$, and $60 \%$ had colostomy $>90$ days.

Table 2 presents that the majority of respondents had spiritual needs in all dimensions. From religious dimension $(88.1 \%)$, inner peace $(57.1 \%)$, existential (54.8\%), and actively giving (52.4\%)

Table 3 describes that all respondents with permanent or temporary colostomy expressed their spiritual needs of all dimensions. In the religious dimension, $47.6 \%$ of respondents with a permanent colostomy and $40.5 \%$ of respondents with a temporary colostomy stated "very" criteria in this dimension. In addition, in the dimension of inner peace $(33.3 \%)$ and existential $(23.8 \%)$, the respondents with permanent colostomy stated "very" need in this dimension. The respondents with temporary colostomy expressed their "very" need in inner peace and existential dimension, respectively $31.0 \%$ and $23.8 \%$.

Table 4 informed that in the religious needs dimension, the majority of respondents $(71.4 \%)$ need to be prayed by their family or others. In addition, the inner peace dimension, $42.9 \%$ of respondents need to find inner peace and for the existential dimension, $47.6 \%$ of respondents expressed their spiritual needs related to forgiving someone from the past. Finally, in the dimension of actively giving $9.5 \%$ of respondents' need were being the solace of others.

\section{Discussion}

Spiritual needs are human needs and expectations in meaning, purpose, and value in their lives (Büssing \& Koenig, 2010). In addition, spiritual needs are the need to seek meaning and purpose in life, the need to love and be loved and the sense of attachment, and the need to give and get forgiveness (Hamid,
2008).

According to the study findings, respondents stated their spiritual needs in all dimensions, namely the religious dimension, inner peace, existential, and actively giving. The religious needs become the most needed, and followed by inner peace, existential, and actively giving. The majority of respondents choose all dimensions of spiritual needs, although they has different levels of needs. In this study, most of the respondents were between 36-60 years old (middle age). Westerhoff's in Hidayat (2006) said that middle age is an age of adulthood with selfconfidence. This development begins with the stronger confidence that is maintained despite the face of different beliefs and more understanding of the self-confidence. The high confidence can affect his spiritual beliefs that also affect his spiritual needs.

The results revealed that the religious dimension as measured by 6 questions, $11.9 \%$ of the respondents stated a little need, and $88.1 \%$ of respondents said very need. These results can illustrate that the dimensions of religiousness fall into the category of greatest need, where religious needs are more focused on one's relationship with God, the religion is an important element in people's lives when they face illness, especially in terms of stress reduction and anxiety (Kozier et al., 2010).

The majority of respondents $(92.9 \%)$ are Muslim. Muslim patients who have a colostomy surgery usually experience various problems in religious rituals. In order to achieve the patient's spiritual well-being, the roles of religious leaders is necessary including asking questions about colostomy to health workers such as doctors and nurses, and supporting patients psychologically this will increase the confidence to live life with colostomy, and perform religious rituals, so as to reduce the occurrence of problems related to the spiritual (Khan, 2011).

In the religious dimension, question items that are very much needed are the need for prayer by family or others as much as $71.4 \%$. This finding in line with Yosalina's (2012) study found that in the religious dimension the highest question was to be prayed by the family $(85.94 \%)$. Likewise in the research Nuraeni (2015) items prayed by family or other people into the question items are 
Rahmatia Mozaike : Spiritual Needs of Patients with A Colostomy

chosen by many respondents. This illustrates that respondents need prayer support from family or others.

From the perspective of Islam, a disease is a test from God. The Islamic teaching encouraged Muslim to pray and dhikr besides doing medical therapy. The prayer and dhikr contain psychotherapeutic elements that can generate confidence and sense of optimism. Both of these are essential for the cure of disease in addition to drugs and medical measures (Hawari, 2002). Wachhlotz and Sambamoorthi's (2011) study found an increase in the positive relationship between pain and prayer behavior over time, indicating the importance of praying as a source of positive coping for respondents.

Nurses as health professionals most often accompany patients and need to assist patients in meeting their religious needs, this can be accomplished by simple activities such as praying with patients, praying for the patient, and providing religious books, and facilitating patients' worship.

A little needed were question items related to reading spiritual books or religious books $(61.9 \%)$. This in agreement with Nuraeni's (2015) study which states that the lowest religious dimension is religious reading $(82.89 \%)$. The World Bank Report No. 16369-IND and the International Association for the Evaluation of Education Achievement in Galus (2011) showed that Indonesian have the lowest rank in reading books (51.7\%), Philippines (52.6\%), Thailand (65, 1), Singapore (74.0\%), Hongkong (75.5). In addition, the ability of Indonesians in mastering reading material and literacy rate only $(65.5 \%)$. In this study, the majority of respondents attended primary education $(57.1 \%)$, a small number of did not have the opportunity to go to school, and the majority of respondents attended 6 years of formal education. Jackson et al (1994) in Bastable (2002) revealed that low levels of education lead to a lack of their ability to read and understand written materials.

The dimension of inner peace consists of 5 questions, in this dimension the respondents stated a little need $(35.7 \%)$, very need $57.1 \%$ and $7.1 \%$ extremely need. In this dimension, the question item that was very much needed is to find inner peace $(42.9 \%)$ and talking with others about fear and worry (35.7\%). This study finding was similar to Diamanti's research (2015) which found that finding the inner peace was the highest item on the dimension of inner peace $(98.6 \%)$. In addition, the finding showed the need for the role of family or another person as a friend to talk or share.

Inner peace is a desire of everyone, according to Mauk and Schmidt (2004) said that inner peace can be obtained by sharing the burden of the mind and creating a comfortable environment. For the majority colostomy patients, this is a frightening experience and cause anxiety and worry, so it is necessary to talk and share with others to reduce fear and anxiety. It is important for nurses to establish therapeutic communication to provide inner peace, listen to the patient while expressing his/her feelings and expressing acceptance to its limitations, to create a quiet, calm, comfortable, and necessary environment to provide certain times for the patient to be alone.

Existential dimension found that the respondents stated rather need $45.2 \%$, and very need as much as $54.8 \%$. In the existential dimension, the question item that is most desperately needed is to forgive a person $(47.6 \%)$. This is in line with Darmanti's research (2015) which shows that in the existential dimension, the most needed question item is forgiving someone $(95.7 \%)$. This illustrates that respondents need others to be forgiven. Forgiveness is one of the positive characters that help individuals achieve optimal levels in terms of physical, psychological, and spiritual health. In addition, forgiving other people's mistakes can be beneficial for both physical and mental health. Forgiving others is also a form of the greatness of soul and behavior that is considered good (Risat, 2015). A somewhat needed question item is to talk to others about the possible life after death (52.4\%). Some of the respondents who attached the colostomy stated that the illness would bring them to death, thus making the respondents prepare for death by increasing spiritual preparedness. Nurses can help patients to meet existential needs through communication or facilitating patients to talk about the meaning and purpose of life, the meaning of pain and suffering and 
Rahmatia Mozaike : Spiritual Needs of Patients with A Colostomy

life after death.

In the actively giving dimension, the respondents stated that they need $45.2 \%$, very need $52.4 \%$, and very very need $2.4 \%$. In this dimension, the question item that is very much needed is to be the solace of others as much as $9.5 \%$. Hawari (2003) said the meaning of people's existence is how much they have beneficial to others. According to Erikson, a man who uses his best time is who puts his thoughts of death before it present and balances by creating happiness by giving whatever he can give as long as he is in the world (Bussing, 2010). This is reinforced by Walton (2002) who revealed that once a person gets help or help from others in times of crisis, there will be a desire to give and can be useful for others to get the balance.

In general, the spiritual needs of permanent colostomy patients have higher spiritual demands on all dimensions of spiritual needs compared with temporary colostomy patients with a proportion of religious dimensions $(47.6 \%)$, inner peace $(33.3 \%)$, existential $(31.0 \%)$, actively giving $(26.2 \%)$. Patients with permanent colostomy felt that they were no longer hopeful to recover as before, but in patients with a temporary colostomy have hope that the stoma can be restored. A person who is required to defecate through bags has a significant impact on the level of hope of healing and life satisfaction in permanent and temporary colostomy patients. This is reinforced by the Taha and Moustafa (2013) study which revealed that patients with temporary colostomies had higher levels of life expectancy and satisfaction compared to patients with a permanent colostomy.

From the four dimensions of spiritual needs are needed by patients a colostomy, although on different levels, so nurses need to pay attention to the spiritual needs of patients and seek spiritual fulfillment. It is therefore important for nurses to examine the individual's spiritual needs for achieving appropriate interventions. Kozier et al. (2010) revealed that spiritual assessment is best performed after nurses foster good therapeutic relationships with patients. To improve the spiritual welfare can be done nursing intervention in the form of offering a person's presence, support the practice of religious worship in the form of praying together, listening to what the patient felt, empathy and respect for the spiritual needs of patients (Kozier et al., 2010; Matson, 2011).

\section{Conclusion}

This study found that the colostomy patient in the hospital stated the spiritual needs with the proportion of religious dimension $(64.3 \%)$, existential (57.1\%), inner peace (54.8\%), and actively giving (50.0\%). Permanent colostomy patients had a higher score of spiritual needs on all dimensions compared to patients with a temporary colostomy. It can be concluded that the religious dimension is a spiritual need with the highest relevance.

\section{Recommendation}

As a health worker, nurses are expected to improve the service of spiritual nursing care through the study of spiritual needs, in addition nurses are expected to assist patients in meeting their spiritual needs by providing supportive religious practices such as praying together with patients, providing spiritual books, assisting in doing worship, establishing therapeutic communication to provide inner peace, talking about the meaning and purpose of life, providing a time to get a feeling of peace, and creating a quiet place and away from the noise.

\section{References}

Baldwin, C., Grant, M., Wendel, C., Rawl, S., Schmidt, C., \& Ko, C. (2008). Influence of intestinal stoma on spiritual quality of life of U.S. veterans. J Holist Nurs, 20, 185-194. Doi:10.1177/0898010108315185.

Bastable, S.B. (2002). Perawat sebagai pendidik: Prinsip-prinsip pengajaran \& pembelajaran. Jakarta: EGC.

Burch, J. (2013). Care of patients with a stoma. Nursing Standard/RNC Publishing, $27,49-56$.

Büssing, A., Balzat, H.J., \& Heusser, P. 
Rahmatia Mozaike : Spiritual Needs of Patients with A Colostomy

(2010). Spiritual needs of patients with chronic pain disease and cancer validation of the spiritual needs questionnaire. Europaean Journal of Medical Research, 266-273.

Büssing, A., \& Koenig, H.G. (2010). Spiritual needs of patients with chronic diseases. Religions, 1, 18-27. doi:10.3390/rel1010018.

Darmanti, P. (2015). Gambaran kebutuhan psikososial dan spiritual pasien dengan penyakit kronis di Rumah Sakit Al-Islam Bandung. Universitas Padjadjaran.

Galus, B.S. (2011). Budaya baca orang Indonesia masih rendah. Retrieved from www.pendidikan.diy.go.id/dinas.v4/?view:v. artikel\&id:8., at August 30, 2017.

Hamid, A.Y. (2008). Bunga rampai asuhan keperawatan kesehatan jiwa. Jakarta: EGC.

Hawari, D. (2002). Dimensi religi dalam praktek psikiatri dan psikologi. Jakarta: FKUI.

Helen, \& Putri, Y.S. (2014). Kualitas hidup pasien dengan stoma permanen di Rumah Sakit Kanker Dharmais. Fakultas Ilmu Keperawatan Universitas Indonesia.

Hidayat, A.A. (2006). Pengantar kebutuhan dasar manusia: Aplikasi konsep dan proses keperawatan. Jakarta: Salemba Medika.

Indonesian Ostomy Association. (2010). Informasi organisasi Indonesian ostomy association. Retrieved from http:// indonesianostomate.blogspot.co.id/, at December 27, 2016.

Johnson, M., Piderman, K., Sloan, J., Huschka, M., Atherton, P., \& Hanson, J. (2007). Measuring spiritual quality of life in patients with cancer. Support Oncol, 5.

Khan, M.A., Jamal, S., Rashid, R., \& Ahmad, N. (2011). Quality of life assessment in patients with stoma in muslim population. Ann. Pakistan Institute Medical Science, 7(4), 222-227.

Kozier, Erb, Berman, \& Snyder. (2010). Buku ajar fundamental keperawatan: Konsep, proses, dan praktik (Edisi 7, Volume 1). Jakarta: EGC.

Maruta, H. (2003). Spiritual pain and its care in patients with terminal cancer: Contruction of a conceptual framework. Philosophical Approach Paliative Care, 1, 15-21.

Mauk, K.L., \& Schmidt, N.K. (2004). Spiritual care in nursing practice. USA: Lippincott \& Wilkins.

Nuraeni, A., Nurhidayah, I., Hidayati, N., Sari, C.W., \& Mirwanti, R. (2015). Kebutuhan spiritual pada pasien kanker. Jurnal Keperawatan Padjadjaran, 3, 57-61.

Rangki, L., Ibrahim, K., \& Nuraeni, A. (2014). Pengalaman hidup pasien stoma pascakolostomi. Jurnal Keperawatan Padjadjaran, 2, 11-22.

Shenoy, K.R., \& Nileshwar, A. (2014). Buku ajar ilmu bedah (Edisi 3, Volume 2). Tangerang: Karisma Publishung Group.

Smeltzer, S.C., \& Bare, B.G. (2002). Buku ajar keperawatan medikal bedah. Jakarta: EGC.

Taha, N.F., \& Moustafa, M.M. (2013). Hope level and life satisfaction among patients with colostomy and their family caregivers. Journal of Biology, Agriculture and Healthcare, 3(13).

Wachholtz, A., \& Sambamoorthi, U. (2011). National trends in prayer use as a coping mechanism for health concerns: Changes from 2002 to 2007.

Walton, J. (2002). Finding a balance: A grounded theory study of spirituality in. Nephrology Nursing Journal, 29(5), 447457.

World Health Organization. (2012). Colorectal cancer incidence, mortality and prevalence worldwide in 2008. Retrieved from http://globocan.iarc.fr., at October 30, 2016. 
Rahmatia Mozaike : Spiritual Needs of Patients with A Colostomy

Yosalina, Y. (2012). Gambaran kebutuhan spiritual pada pasien kanker payudara di RS Hasan Sadikin Bandung. Universitas Padjadjaran.
Yulianti, T. (2016). Gambaran kesejahteraan spiritual pasien dengan stoma usus di RSUP Dr. Hasan Sadikin Bandung. Universitas Padjadjaran. 